\title{
Treating the patient in front of you and the power of language: integrating research into effective clinical practice
}

\author{
Steve Aspinall (1)
}

In a year of great turmoil and hardship for the vast majority of society, it has also been a time for organisations, professional associations and healthcare bodies to come together, working to bring about positive change and give everybody, regardless of who or where they are, the right to rehabilitation. The Community Rehabilitation Alliance and the Arthritis and Musculoskeletal Alliance (http://arma. uk.net) have made great progress in this area, providing a strong voice to guide the future of population health in the UK. Coming together collaboratively has also allowed these collectives to support the efforts for dealing with the current pandemic and the longer-term post viral rehabilitation needs.

Underpinning and supporting this agenda for positive change and effective rehabilitation strategies is our research community and current evidence base, with our understanding, interpretation and application of this evidence being absolutely crucial to the centre of everything we do; patients.

This British Association of Sport Rehabilitators and Trainers (BASRaT)-led issue of the British Journal of Sports Medicine will highlight a number of key issues that can make your practice, as a rehabilitation advocate, clinician and an agent for change, more successful and support the right to effective rehabilitation for everyone.

\section{WHAT'S NEW IN THIS BASRAT ISSUE?}

Supporting the WHO Global Action Plan for Physical Activity, ${ }^{1}$ The International Society for Physical Activity and Health have produced an infographic summarising their 'Eight Key Investments That Work for Physical Activity (PA)' (see page 759). This whole systems approach is crucial for improving population health and underlines the importance of collaborative working and who we need to work with, a 'call for action to everyone, everywhere'. Staying on the topic of physical activity, Trine Moholdt

Correspondence to Steve Aspinall, School of Health and Society, University of Salford, Salford, UK;

s.J.Aspinall@salford.ac.uk and Norwegian colleagues have undertaken a prospective, population-based study examining the adherence to physical activity recommendations for 11-22 years and the risk of all-cause and cardiovascular disease mortality (see page 743). With up to 18 years of mortality follow-up and the measurement of activity patterns over time, this offers unique insights into physical activity for life and why it is never too late to increase your activity levels. During our lifespan, late adolescence can be a period of declining physical activity which has clear implications for adult health. Lubans (University of Newcastle, Australia) and colleagues' 'Burn 2 Learn' two-arm cluster randomised controlled trial used teacher-facilitated High Intensity Interval Training (HIIT) to improve older adolescents' cardiorespiratory fitness (see page 751). Using engaging, practical and submaximal HIIT protocols from earlier work ${ }^{2}$ that could also be easily applied to a wide range of populations, the authors measured changes in cardiorespiratory fitness in addition to secondary outcomes; benefits to muscular fitness and mental health. The 'Burn 2 Learn' trial provides an excellent template for future trials that might also involve long-term behaviour change strategies.

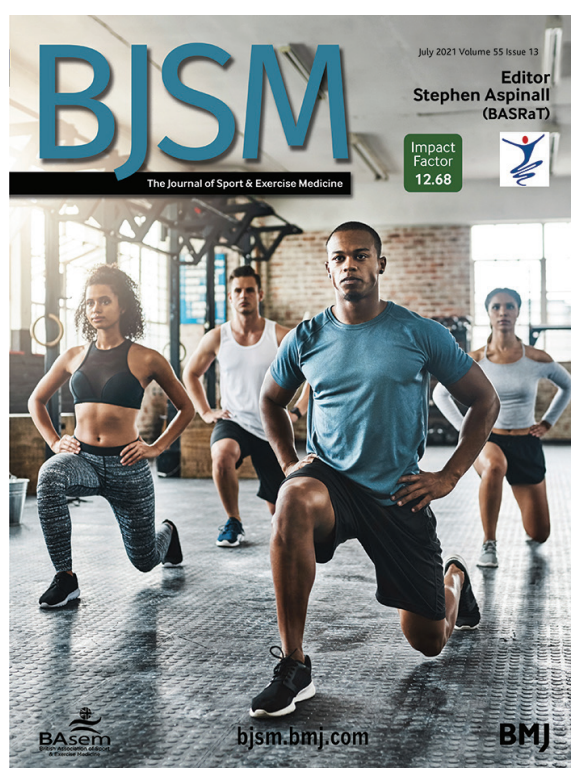

About BASRaT

For fantastic, free international webinars please follow us on twitter or Facebook. The British Association of Sport Rehabilitators and Trainers (BASRaT) is the UK regulator for Sport and Exercise Rehabilitators and an advocate of the multidisciplinary healthcare team. Improving public health by lifestyle and physical activity is a key part of our mission and supporting this, we are proud to be a member of both Arthritis and Musculoskeletal Alliance and the Community Rehabilitation Alliance.

From June 2021, BASRaT registrants will also be part of a global workforce of 75000 healthcare professionals, including the UK, the USA, Canada and Ireland. Overseeing this and ensuring comparable professional and educational standards is CGFNS; the world's largest credentials evaluation organisation for the nursing and allied health professions since 1977.

The BASRaT register of Sport Rehabilitators has been approved as an accredited register by the Professional Standards Authority for Health and Social Care. For more details, please visit us at www.basrat.org

\section{WHAT'S NEW IN EXERCISE \\ PRESCRIPTION?}

One of the leading global causes of years lived with disability is neck pain. ${ }^{3}$ A systematic review with network meta-analysis by Rutger de Zoete and colleagues from Australia and Singapore sheds new light on our prescription of exercise rehabilitation for this condition and why following the currently accepted guidelines might not give our patients the best outcomes, especially when using the commonly prescribed multimodal approach (see page 730 ). Is it time to revisit the current guidelines?

Over the last decade, our knowledge of exercise prescription for special populations has increased considerably and has started to be integrated into educational curricula across healthcare and medicine. ${ }^{4}$ If you are a clinician involved in exercise prescription, then you will undoubtedly have patients with type 2 diabetes. The joint statement of the British and Canadian Associations of Cardiovascular Prevention and Rehabilitation, the International Council for Cardiovascular Prevention and Rehabilitation and the British Association of Sport and Exercise Sciences provides an invaluable guide to glycaemic management during cardiac rehabilitation 
(CR) for this patient population (see page 709). Although the joint statement has a focus on CR, many of the principles can be applied to all exercise rehabilitation settings.

\section{EMPHASIS ON PATIENT-CENTRED CARE}

In this issue, we also have a short editorial and another excellent infographic. Although by nature they are brief, they should stimulate thinking that applies not only to their specific topics but also to the wider realms of patient-centred assessment and treatment. The thoughtful editorial by Robert LaPrade and his Orthopaedic colleagues discusses the science underpinning knee arthroscopy, the importance of a sound clinical assessment along with giving real consideration to the individual patient in front of you (see page 707). The infographic by Adam Culvenor and colleagues from La Trobe University reinforces why we should also treat the patient and not the scan (see page 762). They also succinctly cover an often mentioned but frequently not very applied topic; language matters. For a patient, the words we might use casually can have long lasting effects, both negative and positive, so any opportunities to improve our skills in this area are welcome and can probably benefit not only our patients but us too!

Funding The authors have not declared a specific grant for this research from any funding agency in the public, commercial or not-for-profit sectors.

Competing interests None declared.

Patient consent for publication Not required.

Provenance and peer review Commissioned; internally peer reviewed.

(C) Author(s) (or their employer(s)) 2021. No commercial re-use. See rights and permissions. Published by BMJ.

\section{Check for updates}

To cite Aspinall S. Br J Sports Med 2021;55:705-706.
Accepted 19 April 2021

Br J Sports Med 2021:55:705-706 doi:10.1136/bjsports-2021-104373

ORCID iD

Steve Aspinall http://orcid.org/0000-0003-3045-6466

\section{REFERENCES}

1 World Health Organization. Global action plan on physical activity 2018-2030: more active people for a healthier world. Geneva: World Health Organization, 2018

2 Leahy AA, Eather N, Smith JJ, et al. School-Based physical activity intervention for older adolescents: rationale and study protocol for the burn 2 learn cluster randomised controlled trial. BMJ Open 2019;9:e026029.

3 GBD. 2017 disease and injury incidence and prevalence Collaborators. global, regional, and national incidence, prevalence, and years lived with disability for 354 diseases and injuries for 195 countries and territories, 1990-2017: a systematic analysis for the global burden of disease study 2017. The Lancet 2018:392:1789-858.

4 Gates AB, Kerry R, Moffatt F, et al. Movement for movement: exercise as everybody's business? Br J Sports Med 2017:51:767-8. 